\title{
INFLUENCE OF SOME FOOD INDUSTRY TECHNOLOGIES ON THE CHARACTERISTICS OF PSEUDOMONAS AERUGINOSA STRAINS
}

\author{
O. MRÁZ and JINDRA LUKÁSOVÁ
}

Department of Epizootiology and Microbiology, Department of Food Hygiene and Technology, University of Veterinary Science, 61242 Brno

Received March 13, 1988

Abstract

M $r$ á $z \quad 0 .$, Jindra $L \mathrm{u} \mathrm{k}$ á š o $\mathbf{v}$ á: Influence of Some Food Industry Technologies on the Characteristics of Pseudomonas aeruginosa Strains. Acta vet. Brno, 57, 1988:169-181.

An investigation was made into the effects of 2 and $3 \%$ concentration of $\mathrm{NaCl}, 2.5 \%$ nitrite salting mixture, freezing and milk fermentation on the characteristics of 5 typical Pseudomonas aeruginosa strains isolated from water (1), bull semen (2) and bovine mastitis (2).

The results were as follows:

1. On examination of 75 re-isolated $\underline{P}$. aeruginosa strains qualitative changes were found 12 times, being recorded in a total of 10 (13.3\%) strains. They concerned only dubious to negative attempts at gelatin hydrolysis ( 9 times), pyoverdine loss (twice) and absence of visible gas from $\mathrm{KNO}_{2}$ (once).

Another frequent finding was the loss of blue-green pigmentation on King 's agar A, but the production of pyocyanin in Gessard's medium was unaffected.

2. A total of 55 minor quantitative changes were found in 4 strains of the foregoing group and in 41 (54.7\% other strains. They concerned delayed growth at $41^{\circ} \mathrm{C}$ ( 35 times), production of visible gas from $\mathrm{KNO}_{2}$ only after adaptation passage in nitrate broth (16 times), delayed oxidase reaction (twice), decreased motility (once) and delayed nitrate reduction (once). They occurred mainly in cases where 2 or $3 \% \mathrm{NaCl}$ or nitrite salting mixture was added.

3. In 16 (21.3\%) strains, decreased mortality of mice inoculated i.p. with $0.2 \mathrm{ml}$ of 18 - to $24 \mathrm{~h}$ culture was recorded. Almost half of these strains came from meat-peptone broth containing $2 \% \mathrm{NaCl}$. Involved in this phenomenon were $12(23.5 \%)$ out of 51 aberrant strains and 4 (16.6\%) out of 24 typical strains.

4. Out of 5 virtually unchanged re-isolates, 1 strain from meat-peptone broth with $3 \% \mathrm{NaCl}$ ( 1 week) and 2 strains from yoghurt $(48 \mathrm{~h})$ showed a decrease in $\mathrm{LD}_{50}$, on average, by $29 \%$, nitrite salting mixture ( 2 weeks) the shifts of $\mathrm{LD}_{50}$ were only $-13.1 \%$ and $+1 \%$, respectively. 


\section{Pseudomonas aeruginosa, foodstuffs.}

Food industry tecnnologies are directed towards prolonged keeping possibility, acquisition of a new quality or flavour and, in meat industry, also towards fresh appearance of the product. Undesired bacteria are looked upon as a whole and should be destroyed or at least stopped in their replication during the processing.

Numerous reports on isolation of Pseudomonas aeruginosa from raw milk ( $\mathrm{K}$ i e $1 \mathrm{w}$ e $\mathrm{i} \mathrm{n}$ 1968; $0 \mathrm{t} \mathrm{t}$ e et al. 1978; $\mathrm{K} \mathrm{a} \mathrm{ton} \mathrm{a} \mathrm{and} \mathrm{L}$ á $\mathrm{n} i$ 1982) or meat ( $\mathrm{B} \mathrm{u}$ r z y s k a and $M$ a c i e j s k a 1974; $0 \mathrm{rm}$ a y et al. 1980 are, no doubt, of interest but offer no solution to this special problem. Similarly, little help in this respect can be derived from positive findings of $p$. aeruginosa in baby food ( $\mathrm{B} r \mathrm{r}$ y $\mathrm{n} \mathrm{k}$ a and $\mathrm{M}$ ac $i$ e j s k 1974) or pasterurized milk ( $\mathrm{H} \mathrm{a} 1$ a d o vá and L a c o$v$ á 1979) which rather indicate additional contamination.

In other words, few data are available on the influence of technological factors on the characteristics of microbial species in general. These aspects also remained unnoticed in a monograph ( $\mathrm{J}$ e $\mathrm{d} l i c \check{c} \mathrm{k} \circ \mathrm{v}$ a 1981) and recent food industry manuals $(A \mathrm{r}$ a $i$ and $B$ a $r$ t 1977; $\overleftarrow{S} \mathrm{i} 1 \mathrm{~h}$ á $\mathrm{n} \mathrm{k}$ o $\mathrm{v}$ á 1983) published in our country.

\section{Materials and Methods}

The following strains of $\underline{P}$. aeruginosa were included in the experiments:

$\begin{array}{ll}\left.\text { No. } 39 \text { (CCEB }{ }^{+} 775\right) & \text { isolated from water } \\ \text { No. } 73 \text { (SVÚP 3/82) } & \text { isolated from bul1 semen } \\ \text { No. } 85 \text { (SVÚP 20/82) } & \text { isolated from bul1 semen } \\ \text { No. } 105 \text { (VŠÚPT 37069/83) } & \text { isolated from bovine mastitis } \\ \text { No. } 118 \text { (VSÚPT } 37066 / 83) & \text { isolated from bovine mastitis }\end{array}$

Viewed from the standpoint of systematic bacteriology ( $\mathrm{K}$ r $\mathrm{i}$ e $\mathrm{g}$ and $\mathrm{H}$ ○ $1 \mathrm{t} \mathrm{1984),} \mathrm{al1} \mathrm{the} 5$ strains can be regarded as typical (Table 1). The technological factors under study, their specification and the lengths of exposure are shown in the following survey:

a) $\mathrm{NaC1}$ (in meat-peptone broth):

$2 \%$ concentration: $24 \mathrm{~h}, 48 \mathrm{~h}, 1$ week

$3 \%$ concentration: $24 \mathrm{~h}, 48 \mathrm{~h}, 1$ week

b) Nitrite salting mixture (in meat-peptone broth):

$2.5 \%$ concentration: $24 \mathrm{~h}, 1$ week, 2 weeks

c) Freezing (freshly pasteurized egg melange): exposure to - $18^{\circ} \mathrm{C}: 1$ week, 2 weeks, 4 weeks

d) Lactic acid fermentation (preparation of yoghurt and its storage): incubation at $43^{\circ} \mathrm{C}: 3 \mathrm{~h}$ storage at $10^{\circ} \mathrm{C}: 24 \mathrm{~h}, 48 \mathrm{~h}$.

After experimental contamination of the individual substrates $\left(10^{6}\right.$ to $10^{10}$ microbial cells $\cdot \mathrm{ml}^{-1}$ ) and subsequent incubation the inoculations

${ }_{\text {CCEB }}=$ Czechoslovak Collection of Entomogenous Bacteria, Prague

SVÚP = State Veterinary Institute, Pardubice

VŠ́UP = Plant Breeding Research Institute, Troubsko 
Table 1

Characteristics of the used strains of Pseudomonas aeruginosa

\begin{tabular}{|c|c|c|c|c|c|}
\hline & \multicolumn{5}{|c|}{ Diagnostic features: } \\
\hline Rods & + & + & + & $\begin{array}{c}+--- \\
+\end{array}$ & + \\
\hline Motility & + & + & + & + & + \\
\hline Gram & - & - & - & - & - \\
\hline Relation to $\mathrm{O}_{2}$ & aerobe & aerobe & aerobe & aerobe & aerobe \\
\hline Growth at $41^{\circ} \mathrm{C}$ & + & + & + & + & + \\
\hline \multicolumn{6}{|l|}{ Formation of : } \\
\hline Catalase & + & + & + & + & + \\
\hline Oxidase & + & + & + & + & + \\
\hline Pyocyanine & + & + & + & + & + \\
\hline Pyoverdine & + & + & + & + & + \\
\hline Nitrate reduction & + & + & + & + & + \\
\hline Denitrification & + & + & + & + & + \\
\hline Haemolysis (ovine r. c) & + & + & + & + & + \\
\hline Milk peptonization & + & + & + & + & + \\
\hline \multicolumn{6}{|l|}{$0-F$ test in: } \\
\hline Glucose & 0 & 0 & 0 & 0 & 0 \\
\hline Maltose & - & - & - & - & - \\
\hline \multicolumn{6}{|l|}{ Hydrolysis of: } \\
\hline Acetamide & + & + & + & + & + \\
\hline Arginine & + & + & + & + & + \\
\hline Gelatin & + & + & + & + & + \\
\hline Starch & - & - & - & - & - \\
\hline Tween 80 & + & + & + & + & + \\
\hline 0-antigen & 4 & 1 & 11 & 3 & 6 \\
\hline \multicolumn{6}{|l|}{ Pathogenicity for: } \\
\hline White mouse: per os & - & - & - & - & - \\
\hline i. p. & + & + & + & + & + \\
\hline
\end{tabular}


Table 2

Frequency of changes in characteristics of $P$. aeruginoss strains after the experiments carried out

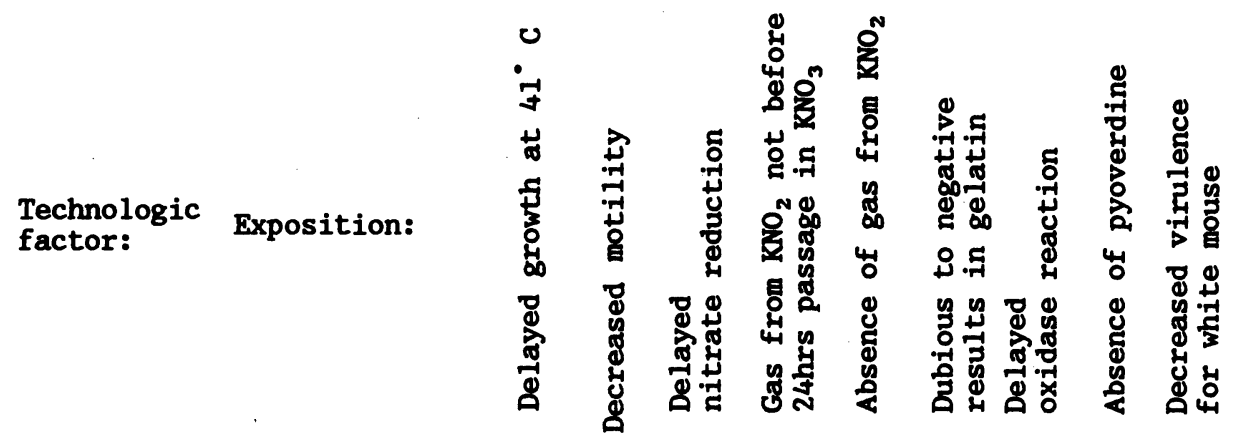

\begin{tabular}{|c|c|c|c|c|c|c|c|c|c|c|}
\hline \multirow{3}{*}{$\begin{array}{c}2 \% \text { of } \mathrm{NaCl} \\
\text { (broth) } \\
37^{\circ} \mathrm{C}\end{array}$} & $24 \mathrm{hrs}$ & 5 & & & & & \multirow[b]{3}{*}{1} & & & 3 \\
\hline & $48 \mathrm{hrs}$ & 5 & & & 1 & & & & \multirow{2}{*}{$\therefore$} & 3 \\
\hline & 1 week & 5 & & & 1 & & & & & 1 \\
\hline \multirow{3}{*}{$\begin{array}{c}3 \% \text { of } \mathrm{NaCl} \\
\text { (broth) } \\
37^{\circ} \mathrm{C}\end{array}$} & $24 \mathrm{hrs}$ & 4 & & & 1 & & & & & \\
\hline & $48 \mathrm{hrs}$ & 3 & & & 2 & & & & & 2 \\
\hline & 1 week & 5 & & & 2 & & & & & 1 \\
\hline \multirow{3}{*}{$\begin{array}{c}2.5 \% \\
\text { of nitrite } \\
\text { salting } \\
\text { mixture } \\
\text { (broth) } \\
37^{\circ} \mathrm{C}\end{array}$} & $24 \mathrm{hrs}$ & 2 & & & 2 & & & 1 & & 1 \\
\hline & 1 week & 2 & & & 1 & & 2 & & 1 & 1 \\
\hline & 2 weeks & & & 1 & & 1 & 1 & & 1 & 1 \\
\hline \multirow{3}{*}{$\begin{array}{l}\text { Freezing } \\
\text { (egg melange) } \\
-18^{\circ} \mathrm{C}\end{array}$} & 1 week & & & & 1 & & 1 & 1 & & 2 \\
\hline & 2 weeks & 2 & & & 2 & & 1 & & & 1 \\
\hline & 4 weeks & & & & & & 1 & & & \\
\hline \multirow{3}{*}{$\begin{array}{c}\text { Fermentation } \\
\text { of milk } \\
\text { (youghurt) }\end{array}$} & $3 \mathrm{hrs} / 43^{\circ} \mathrm{C}$ & & & & 1 & & & & & \\
\hline & $24 \mathrm{hrs} / 10^{\circ} \mathrm{C}$ & 2 & 1 & & 2 & & 1 & & & \\
\hline & $48 \mathrm{hrs} / 10^{\circ} \mathrm{C}$ & & & & & & 1 & & & \\
\hline \multicolumn{2}{|c|}{ Changes on the whole } & 35 & 1 & 1 & 16 & 1 & 9 & 2 & 2 & 16 \\
\hline
\end{tabular}


were made on Pseudomonas agar F IMUNA. For evaluation of 24- to 48-h cultures grown at $30^{\circ} \mathrm{C}$, an UV lamp was used so that one suspect colony each could also be taken for bacteriological examination.

The re-isolated strains were examined for 20 diagnostic features as specified in Table 1 . In addition to this, antigenic structure (0-serovar) and virulence for white mice were retested. The techniques used in our study are in keeping with those described in standard manuals ( $\mathrm{C}$ a $\mathrm{r}$ e $r$ 1973; $\mathrm{C} O \mathrm{w}$ a $\mathrm{n}$ and $\mathrm{S} t$ e e 1 1974; S t a r et al. 1981; Krieg and $H \circ 1$ t 1984) and recent relevant reports (A r a $i$ et al. 1970). They were cited in full in a previous study by M r á z (1987) who also suggested some improvements:

1) Relation to molecular oxygen is tested by inoculation into $0.3 \%$ meat-peptone agar containing $0.5 \mathrm{~g}$ sodium thioglycolate and $0.15 \mathrm{ml}$ of $1 \%$ aqueous solution of resazurin per 1 litre medium.

2) Motility is assessed on the basis of diffuse growth after inoculation into semi-solid agar ad 1) supplemented with $0.1 \% \mathrm{KNO}_{3}$. In negative and dubious cases the hanging drop technique is used in addition.

3) Denitrification ability is examined in anaerobic meat-peptone broth with $0.1 \% \mathrm{KNO}_{2}$ and with an inverted Durham gas tube. Incubation at $37{ }^{\circ} \mathrm{C}$ is carried out for no longer than 10 days. Possible negative (defective or anaerogenic) strains can be completed by 24-h passage in nitrate broth (P a 1 e r o $i$ and $D \circ u d \circ r \circ f$ 1972).

4) Pyocyanin production is tested using a modification of $G$ e s $s$ a $r$ d (1981) medium ( $1 \%$ glycerol and $2 \%$ Bacto-Protone or Neoptone Difco in distilled water) incubated at $30^{\circ} \mathrm{C}$ for 5 days.

The virulence of the strains was tested in groups of 2 mice each inoculated i.p. with $0.2 \mathrm{ml}$ of $18-$ to $24-\mathrm{h}$ broth culture and in separate experiments per os using contaminated feed tablets. Moreover, the $\mathrm{LD}_{50}$ ( $R$ e e d and $M u$ e $n$ h 1938) was determined in all 5 starting strains and in 5 virulent re-isolates.

\section{Results}

The effects of technological factors were found in 51 (68\%) out of $75 \mathrm{P}$. aeruginosa re-isolates (Table 2). A total of 67 changes shown by the strains can be divided into two groups:

a) Qualitative changes in the diagnostic sense were recorded 12 times, being found in 10 (13.3\%) strains. They concerned only dubious to negative attempts at gelatin hydrolysis (9 times), loss of pyoverdine (twice) and absence of visible gas from $\mathrm{KNO}_{2}$ (once). Another frequent phenomenon was the loss of blue-green pigmentation on King 's agar A, but the production of pyocyanin in the modified Gessard medium remained unaffected.

b) A total of 55 minor quantitative changes were found in 4 strains of the foregoing group and in 41 (54.7\%) other strains. They concerned delayed growth at $41^{\circ} \mathrm{C}$ (35 times), 
production of visible gas from $\mathrm{KNO}_{2}$ only after adaptation passage in nitrate broth (16 times), delayed oxidase reaction (twice), decreased motility (once) and delayed nitrate reduction (once). They occured mainly in meat-peptone broth containing 2 or $3 \% \mathrm{NaCl}$ or nitrite salting mixture.

In certain agreement with the aforementioned data was the finding of $16(21.3 \%)$ cases of decreased mortality in i.p. inoculated mice. Involved in this phenomenon were $12(23.5 \%)$ out of 51 aberrant strains and 4 (16.6\%) out of typical strains. The highest frequency ( 7 times) was recorded for meat-peptone broth containing $2 \% \mathrm{NaCl}$ from which also the majority (3) of entirely innocuous strains came. All 75 mouse pairs fed $\underline{P \text {. aeruginosa cultures }}$ survived.

The antigenic structure (O-serovar) showed no changes during the experiments.

Table 3 shows the results obtained in 15 re-isolates each of the 5 starting strains. It can be seen that the number of changes ranged from 10 to 15, averaging 13.4 (0.9 per re-isolate). Decreased mortality of mice was observed mainly in re-isolates of strain No. 39 from water and strain No. 85 from bull semen.

Bioassays for determination of the $\mathrm{LD}_{50}$ in the 5 starting strains and 5 virulent re-isolates were carried out almost concurrently and in immediate continuation of the density determination of their 18- to 24-h broth cultures (Table 4). Comparison of the results shows that the $\mathrm{LD}_{50}$ of re-isolates of strains Nos. 73,85 and 105 was 17.9 to $43.1 \%$ lower, whereas in the re-isolates of strains Nos. 39 and 118 the shifts of $\mathrm{LD}_{50}$ were only -13.1 and $+1 \%$, respectively.

\section{Discussion}

It is well-known that changes in the environment may produce more or less pronounced changes in the characteristics of bacteria. The extent and intensity of this variability are of many-sided importance, being of value, among other things, to bacteriological diagnostics. This question was therefore considered by us concurrently with our investigation into the effects of some technological processes on the survival of $P$. aeruginosa in foods ( $\mathrm{L}$ u k á š o $\mathrm{v}$ á and M r á z 1986). 


\section{Frequency of changes in re-isolates of $p$. aeruginosa}

according to the starting strains

\begin{tabular}{|c|c|c|c|c|c|c|c|c|c|c|}
\hline $\begin{array}{l}\text { Re-isolates } \\
\text { ( } 15 \text { each) } \\
\text { of starting } \\
\text { strain No: }\end{array}$ & 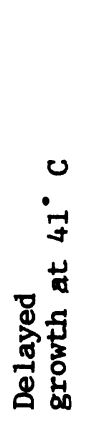 & 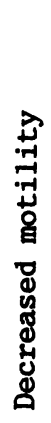 & 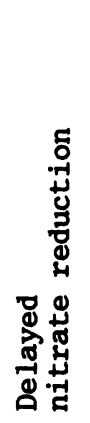 & 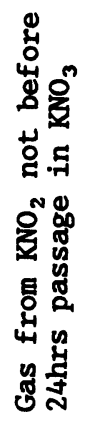 & 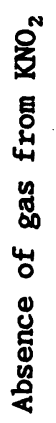 & 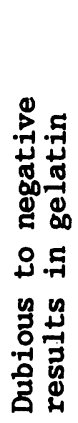 & 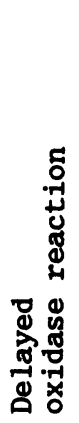 & 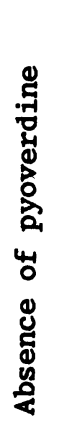 & 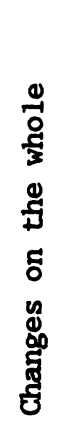 & 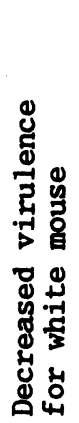 \\
\hline 39 & 6 & & & 3 & & & 1 & & 10 & 5 \\
\hline 73 & 8 & & & 5 & & 2 & & 2 & 17 & 3 \\
\hline 85 & 7 & 1 & & 3 & & & 1 & & 12 & 5 \\
\hline 105 & 9 & & 1 & 3 & 1 & 1 & & & 15 & 2 \\
\hline 118 & 5 & & & 2 & & 6 & & & 13 & 1 \\
\hline Altogether & 35 & 1 & 1 & 16 & 1 & 9 & 2 & 2 & 67 & 16 \\
\hline
\end{tabular}

The changes in the biochemical characteristics were mainly quantitative. In gelatin, however, where the proportion of dubious to negative cases was $12 \%$, a qualitative aberration is indicated. In practice it means that this characteristic should be assigned the sign of $d$ or $v$.

A rather surprising finding was the $29.3 \%$ absence of blue-green pigmentation on King 's agar A which is generally regarded as specific and very sensitive. Even though it is probable that the proportion of positive results might be increased by cutting the cultures and shaking out possible pyocyanin into chloroform, it seems more useful to choose Gessard's modified medium.

Further biochemical examinations demonstrated a considerable value of the test for acetamide hydrolysis ( $\mathrm{r}$ a i et al. 1970) and the usefulness of the employed denitrification technique in pseudomonads. 


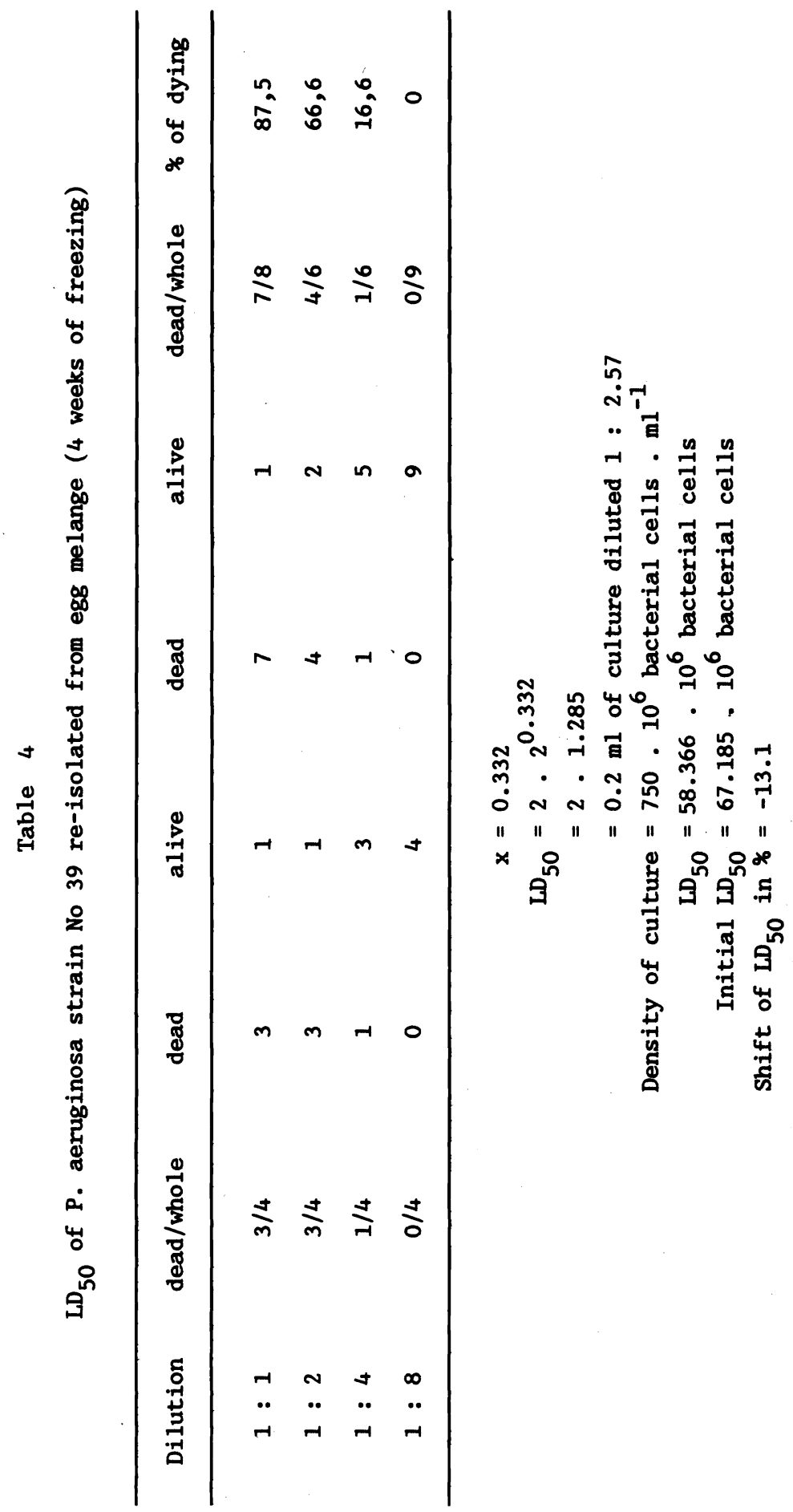




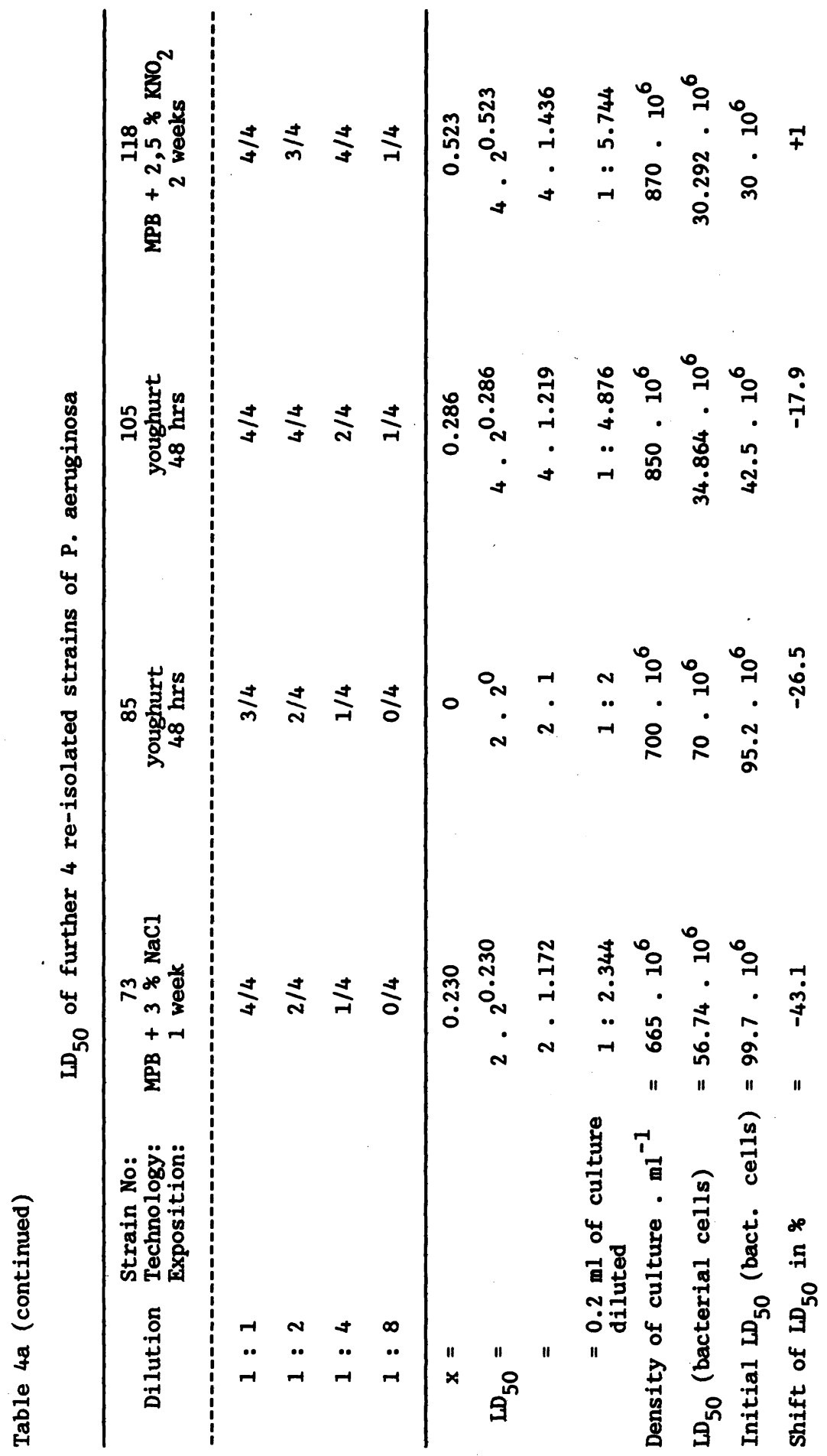


The evidence from the bioassays on mice suggests that involved in the 16 dubious to negative results was not only the nutrient medium (mainly meat-peptone broth containing $2 \% \mathrm{NaCl}$ ) but also the biochemical lability of some re-isolates. In this connexion it should be noted that decreased mortality to complete innocuity was found mainly in aberrant strains (cca by $7 \%$ ).

The determinations of $\mathrm{LD}_{50}$ suggest that the virulence of pseudomonads can more or less increase in certain environments (particularly in yoghurt). From Table 4 it also appears that in routine bioassays on mice an i.p. dose of $0.2 \mathrm{ml}$ of $18-$ to $24-\mathrm{h}$ broth culture is preferable to the $0.1 \mathrm{ml}$ dose used hitherto.

Of certain value is also the fact that all the re-isolates of $P$. aeruginosa were innocuous for mice when administered per os. In our view, this observation might be used for more favourable evaluation of microbial findings in feeds and some foods.

\section{Vliv některých potravinářských technologií na vlastnosti kmenů Pseudomonas aeruginosa}

V práci byl zkoumán vliv 2 a $3 \%$ koncentrace $\mathrm{NaCl}, 2,5 \%$ dusitanové solicí směsi, mražení a mléčného kysání na vlastnosti 5 typickiých kmenů $\underline{P}$. aeruginosa $\mathrm{z}$ vody (1), býčího spermatu (2) a bovinní mastitidy (2).

Dosažené výsledky:

1) Z 75 reizolovaných kmenů $P$. aeruginosa byly kvalitativní změny zjištěny celkem $12 x$, a to u $10(13,3 \%)$ kmenů . Týkaly se jen dubiózních až negativních pokusů o hydrolýzu želatiny $(9 \mathrm{x})$, ztráty pyoverdinu $(2 \mathrm{x})$ a absence viditelného plynu z $\mathrm{KNO}_{2}(1 \mathrm{x})$. Častým úkazem byla i ztráta modrozelené pigmentace na Kingově agaru $A$, ale tvorba pyocyaninu v modifikovaném Gessardově médiu zůsstala zachována.

2) Drobných kvantitativních změn bylo zjištěno celkem 55, a to $u 4$ kmenů $z$ předchozí skupiny, a zbytek $u 41$ $(54,7 \%)$ dalších kmenů. Týkaly se opožděného růstu pr̆i $41{ }^{\circ} \mathrm{C}(35 \mathrm{x})$, tvorby viditelného plynu $\mathrm{z} \mathrm{KNO}_{2}$ až po adaptační pasáži $\mathrm{v}$ nitrátovém bujónu $(16 \mathrm{x})$, opožděné reakce 
na oxidázu ( $2 x)$, snížené pohỳblivosti (1x) a opožděné redukce nitrátu (1x). Vyskytovaly se hlavně za přídavku 2 a $3 \% \mathrm{NaCl}$ a dusitanové směsi.

3) U 16 (21,3 \%) kmenů došlo ke snížení úhynu u naočkovaných myší $(0,2 \mathrm{ml} 18$ - 24hod. bujónové kultury i.p.), $\mathrm{z}$ toho téměr̆ $\mathrm{v}$ polovině případů (u $7 \mathrm{kmenů)}$ ve spojitosti $\mathrm{s} 2 \% \mathrm{NaCl} \mathrm{v}$ masopeptonovém bujónu. $\mathrm{Z}$ jiného pohledu lze říci, že se na tomto počtu podílelo $12(23,5 \%)$ z $51 \mathrm{kme}-$ nů aberantních a $4(16,6$ \%) z 24 kmenů typických.

4) Z 5 vesměs nezměněných reizolant se $L_{50} u 1$ kmene $\mathrm{z}$ masopeptonového bujónu s $3 \% \mathrm{NaCl}$ (1 týden) a $2 \mathrm{kmenů}$ $\mathrm{z}$ jogurtu (48 hodin) $\mathrm{v}$ průměru $029 \%$ snížila, zatímco u 1 kmene $z$ mražené vaječné melanže ( 4 týdny) a 1 kmene $\mathrm{z}$ pasopeptonového bujōnu s 2,5\% dusitanové směsi ( 2 týdny) činil zjištěný posun $\mathrm{LD}_{50}$ jen $-13,1$ a $+1 \frac{\%}{8}$.

Влияние некоторых пищевых технологий на свойства штаммов Pseudomonas aeruginosa

В работе проводились исследования влияния 2 и 3\% концентрации хлористого натрия, 2,5\% нитритного рассола, замораживания и молочной закваски на свойства 5 типичных штаммов $P$. aeruginosa из вопы (1), бычей спермы (2) и воспаления вымени коров (2).

Достигнутые результаты:

1) Из 75 реизолированных штаммов P. aeruginosa качественные изменения были установлены в итоге в 12 раз, а именно У 10 (13,3\%) штаммов. Они касалиь сомнительных даже негативных попыток гидролиза желатина (9 раз), потери пиовердина (2 раза) и отсутствия видимого газа из $\mathrm{KNO}_{2}$ (1 раз). Часто встречающимся явлением стало исчезновение сине-зеленой пигментации на агаре Кинга $A$, однако образование пиоцианина в модифицированной среде Гессарда оставалось.

2) Незначительных количественных изменений было выявлено в итоге 55, в частности, у 4 штаммов предыдущей группы, остаток у $41(54,7 \%)$ других штаммов. Они касались запоздалого роста при $41^{\circ} \mathrm{C}(35$ раз) образования видимого газа из $\mathrm{KNO}_{2}$ только после адап- 
тивного прохохдения в нитратном бульоне (16 раз), запоздалой реакции на оксудазу (2 раза), пониженной подвижности ( 1 раз) и запоздалой редукции нитрата (1 раз). Они встречались, главным о6разом, при добавке 2 и $3 \%$ хлористого натрия и нитритной смеси.

3) В случае $16(21,3 \%)$ штаммов произошло понижение отхода $y$ привитых мыей $(0,2$ мл бульонной культуры i.p.), из этого почти в половине случаев (7 штаммов) в связи С $2 \%$ хлористым натрием в мясопептоновом бульоне. С другой точки следует отметить, что из 51 отличающегося штамма в данную численность входило $12(23,5 \%)$ штаммов и из 24 типичных штаммов - 4 (16,6\% ) штамма).

4) Из 5 большей частью не измененных реизолянтов $\mathrm{LD}_{50}$ Y 1 mтамма из масопептонового бульона С 3\%. Хर०ристого натрия (1 неделя) и 2 штаммов из югурта (48 часов) в среднем на 298 понизилась, между тем как $y$ штамма из замороженной яичной смеси ( 4 недели) и 1 штамма из масопептонового бульона с 2,5\% нитритной смеси ( 2 недели) Установленный сдвиг $\mathrm{LD}_{50}$ достигал лишь $-13,1$ и +1 \%.

\section{References}

ARAI T. - OTAKE M - ENOIYOTO S. et al.: Determination of Pseudomonas aeruginosa by biochemical test methods. Japan J. Microbio1., 14, 1970: 279 - 284 .

ARPAI J. - BARTL V.: Potravinárska mikrobiológia. Alfa, Bratislava 1977, 280 p.

BURZYNSKA H. - MACIEJSKA K.: Wstepne rozpoznanie wystepowania Pseudomonas aeruginosa w srodkach spozywczych. Rocz. Panstw. Zak1. Hig., 25, 1974: $641-647$.

CARTER G. R.: Diagnostic Procedures in Veterinary Microbiology. 2. edit. CH. C. Thomas, Springfield 1973, 362 p.

COWAN S. T. - K. J. STEEL: Cowan and Steel's Manual for Identification of Medical Bacteria. 2. edit. Cambridge Univ. Press, London 1974, 238 p.

GESSARD M. C.: Des races du bacille pyocyanique. Ann. Inst. Pasteur, $\underline{5}$, 1891: 65 - 78 .

HALADOVÅ E. - LACOVÁ M.: Výskyt Pseudomonas aeruginosa v pasterovaném mléce. Cs. hyg., 24, 1979: $447-450$.

JEDLIČKovå Z.: Pseudomonas aeruginosa. Academia, Praha 1981. 131 p. 
KATONA F. - LANYY B.: Hygienic aspects of the presence of Pseudomonas aeruginosa in raw milk. XXI. Int. Dairy Congress, Moskva 1982.

KIELWEIN G.: Pseudomonas aeruginosa: Untersuchungen in Rohmilch und die bakteriologische Charakterisierung. Arch. Lebensmittelhyg., 19, 1968: 145

KÖHLER W.: Pseudomonas aeruginosa (Bact. pyocyaneum): Cytologie, Biochemie und Serologie. Wissenschaft1. Zschr. Univ. Rostock. Math.-nat. Reihe 7, 1957/58: 25.

KRIEG N. R. - HOLT J. G. (Ed.): Bergey's Manual of Systematic Bacteriology. Vo1. I. Williams and Wilkins, Baltimore 1984, 964 p.

LUKÁS̄OVÁ J. - MRÁZ 0.: Effect of some technological processes on the survival of Pseudomonas aeruginosa in foods. Acta vet., Brno, 55, 1986: 353

- 358.

MRÁZ O.: A contribution to the identification of Pseudomonas aeruginosa. Acta vet. Brno, 56, 1987: 115 - 122 .

ORMAY L. - JÁNOSSY L. - TARJAN R.: Supposed role of pseudomonads in food poisoning. In: MUZIKÁR V. - BARTL V. (Ed.): Nové poznatky z potravinár̆ské mikrobiologie a minisymposium Pseudomonas. Sbornik přednášek ze semináře Cs. spol. mikrobiol. při CSAV v Praze, Liblice 3. - 5. 11. 1980, $236 \mathrm{p}$.

OTTE I. - HAHN G. - TOLLE A.: Vorkommen, Nachweis und Bedeutung von Pseudomonas aeruginosa in Rohmilch und in der Ungebung von Milchtieren. Milchwissenschaft, 33 , 1978: 737 - 739.

PALLERONI N. J. - DOUDOROFF M.: Some properties and taxonomic subdivisions of the genus Pseudomonas. Ann. Rev. of Phytopathology, 10, 1972: 73 100.

REED L. F. - MUENCH H.: A simple method of estimating 50 per cent endpoints. Amer. J. Hygiene, 27, 1938: 493 - 497.

STARR M. P. - STOLP H. - TRUPER H. G. et al.: The Prokaryotes. Vo1. I. Springer-Verlag, Berlin-Heidelberg-New York 1981, 1102 p.

SILHÁNKOVÃ L.: Mikrobiologie pro potravináře. SNTL, Praha 1983, 298 p. 